\title{
A MEDIAÇÃO DA LEITURA LITERÁRIA: UMA PROPOSTA DE METODOLOGIA TEMÁTICA ${ }^{1}$
}

\author{
MEDIATION OF LITERARY READING: A PROPOSAL OF \\ THEMATIC METHODOLOGY
}

\author{
Suéllen Pereira Miotto LOURENÇO ${ }^{2}$ \\ Maria Amélia DALVI ${ }^{3}$
}

\begin{abstract}
Resumo: O artigo aborda teoricamente o papel social da literatura, se oportunizada sua apreciação estética; defende que, assim, a experiência com o texto literário torna-se concreta e a mediação do professor permite ao educando experienciar o mundo por meio da palavra. Ancoradas em noções conceituais bakhtinianas e nas reflexões sobre a literatura e a leitura de Antonio Candido e Paulo Freire, tematizamos a promoção de uma leitura literária dialógica e apresentaremos possibilidades de exploração do texto literário a partir de uma experiência de leitura e análise de obras que se aproximam tematicamente. Para tal, selecionamos dois livros: Boitempo, de Carlos Drummond de Andrade, e Minha vida de menina, de Helena Morley. Discorreremos a respeito de como se constroem as relações familiares no contexto de cada obra (o que servirá de exemplo do que denominamos como metodologia temática), destacando o importante papel do professor como mediador nesse processo que visa à formação de sujeito leitor crítico e consciente de seu papel social.
\end{abstract}

Palavras-chave: Leitura. Literatura. Leitura literária. Mediação. Texto literário.

Abstract: This paper theoretically addresses the social role of aesthetically appreciated literature; it argues that this experience with the literary text becomes concrete and teacher's mediation allows the learner to experience the world through words. Anchored on Bakhtin's conceptual notions and Antonio Candido's and Paulo Freire's reflections on literature and reading, we discuss the promotion of a dialogical literary reading and present possibilities of exploration of literary texts based on an experience of reading and analyses of works that are thematically related. For that, we selected two books: Boitempo, by Carlos Drummond de Andrade, and Minha vida de menina, by Helena Morley. We discuss how family relations are constructed in the context of each work (which will serve as an example of what we call thematic methodology), highlighting the important role of the teacher as a mediator in this process that aims at the formation of a critical and conscious reader who is aware of his or her social role.

Keywords: Reading. Literature. Literary reading. Mediation. Literary text.

\footnotetext{
${ }^{1}$ Este artigo decorre da articulação inédita de duas pesquisas no âmbito do Grupo de Pesquisa Literatura e Educação (www.literaturaeeducacao.ufes.br): uma primeira, sobre memórias literárias da escolarização, tomando como corpus literário principal as obras Boitempo, de Carlos Drummond de Andrade, e Minha vida da menina, de Helena Morley, com resultados publicados em Dalvi e Salgueiro (2016), Dalvi (2016, 2017a, 2017b, 2017c) e em Dalvi e Camargo (2017); e uma segunda, em curso, sobre educação literária a partir de metodologia temática, em desenvolvimento junto ao curso de doutoramento em Letras (área de concentração: Estudos Literários), no âmbito do Programa de Pós-Graduação em Letras da Universidade Federal do Espírito Santo.

${ }^{2}$ Doutoranda em Letras pelo Programa de Pós-Graduação em Letras da Universidade Federal do Espírito Santo e professora no magistério da Educação Básica, Técnica e Tecnológica do Instituto Federal do Espírito Santo (campus Nova Venécia). E-mail: suellen.miotto@ hotmail.com.

${ }^{3}$ Doutora em Educação e professora junto ao Departamento de Linguagens, Cultura e Educação e aos Programas de Pós-Graduação em Educação e em Letras da Universidade Federal do Espírito Santo. E-mail: maria.dalvi@ufes.br.
} 


\section{Introdução}

\subsection{A leitura como questão para a educação brasileira}

A série de estudos e publicações denominada Retratos da Leitura no Brasil vem, desde 2001, produzindo, sistematizando e analisando dados e indicadores que possibilitem a (re)orientação de programas e projetos de inclusão cultural para a população brasileira, além de identificar fatores que levem à leitura e promovam o acesso ao livro (FAILLA, 2016). A pesquisa instiga muitas indagações com os seus números, mas uma constatação já pôde ser feita, em todas as edições: o Brasil ainda não atingiu os níveis satisfatórios para que possamos afirmar que temos um público comprometido com os hábitos de leitura e tampouco conseguiu formar uma população majoritariamente autônoma e crítica no que diz respeito à experiência de leitura - ao menos, com o tipo de leitura que os métodos daquela pesquisa permitem capturar.

Complementarmente aos dados das sucessivas edições de Retratos da Leitura no Brasil, podemos considerar resultados preocupantes do desempenho brasileiro em leitura em diferentes âmbitos; para ficar apenas em dois exemplos recentes, relembramos:

a) o fato de o país ocupar há mais de uma década uma péssima posição no "ranqueamento" promovido pelo PISA (Programa Internacional de Avaliação de Estudantes ou, no original, Programme for International Student Assessment - iniciativa de avaliação comparada, aplicada de forma amostral a estudantes matriculados a partir do $7^{\circ}$ ano do ensino fundamental na faixa etária dos 15 anos, sob coordenação da Organização para Cooperação e Desenvolvimento Econômico, que avalia o desempenho em leitura, cálculo e ciência elementar) - na última edição, ficamos na $65^{\mathrm{a}}$ classificação entre 70 países participantes; e

b) o impacto sobre a vida política do país ${ }^{4}$, decorrente do compartilhamento acrítico de "fake news" (notícias falsas) por meio de diferentes recursos digitais, na maior parte das vezes

\footnotetext{
${ }^{4}$ Diversos portais jornalísticos de larga tradição e credibilidade produziram notícias e reportagens sobre o impacto das chamadas "fake news" no processo eleitoral brasileiro, no ano de 2018; entre eles: a) BBC Brasil ("Um Brasil dividido e movido a notícias falsas: uma semana dentro de 272 grupos políticos no WhatsApp". Fonte: <https://www.bbc.com/portuguese/brasil-45666742>. Acesso: 28 mar. 2019); b) Revista Exame ("Disseminação de "fake news" para atacar candidatos marca eleição". Fonte: <https://exame.abril.com.br/brasil/disseminacao-defake-news-para-atacar-candidatos-marca-eleicao/>. Acesso: 28 mar. 2019); c) Agência Brasil ("Fake news sobre candidatos inundam redes sociais em período eleitoral". Fonte: <http://agenciabrasil.ebc.com.br/geral/noticia/2018-10/um-dia-da-eleicao-fake-news-sobre-candidatos-inundamredes-sociais>. Acesso: 28 mar. 2019); d) Valor Econômico ("Brasil é $1^{\circ}$ caso de fake news maciça para influenciar votos, diz OEA". Fonte: <https://www.valor.com.br/politica/5948635/brasil-e-1-caso-de-fake-news-macica-parainfluenciar-votos-diz-oea>. Acesso: 28 mar. 2019), e e) El País Brasil (“A máquina de 'fake news' nos grupos a favor de Bolsonaro". Fonte: <https://brasil.elpais.com/brasil/2018/09/26/politica/1537997311_859341.html>. Acesso: 28 mar. 2019).
} 
pela incapacidade de reconhecer indícios de um texto de procedência duvidosa e desamparado de elementos de credibilidade (fonte, assinatura, contexto, integralidade do texto ou da citação etc.). ${ }^{5}$

Sem ignorar a importância da expansão/consolidação do mercado editorial e das políticas públicas devotadas ao livro e à leitura (por exemplo, os milhões investidos em programas tais como o Programa Nacional para o Livro Didático, o Programa Nacional para a Biblioteca Escolar, os Acervos Literários do Pacto Nacional pela Alfabetização na Idade Certa); e dos esforços da sociedade civil organizada devotados ao fomento à cultura letrada e à leitura, os resultados apresentados por esse conjunto de dados mencionados acima (pesquisa Retratos da Leitura no Brasil, desempenho do Brasil no PISA e consequências do compartilhamento maciço de "Fake News" em razão da dificuldade de reconhecer indícios de textos de procedência e teor duvidosos) nos levam a questionar: Como, na condição de profissionais da educação e pesquisadores, poderíamos contribuir para formar sujeitos leitores? Quais práticas seriam mais efetivas na mediação da leitura e, particularmente, da leitura literária ${ }^{6}$ ?

Este é um dos vários desafios da escola pública brasileira: a formação de leitores e a promoção da leitura - e particularmente a formação de leitores literários e a promoção da leitura literária. Isso porque, segundo a própria série Retratos da Leitura no Brasil, é dentro dela (a escola pública), mais do que em outras instituições, que os educandos mais se encontram com os livros para fins diversos.

O panorama delineado acima nos faz refletir sobre o papel que o professor de Língua Portuguesa e Literatura exerce como mediador nas leituras feitas pelos alunos em contexto escolar. Mediação que exige sensibilidade, conhecimento do campo, apreço à leitura (literária) e à cultura letrada, além, é claro, de condições materiais objetivas que as favoreçam.

\footnotetext{
${ }^{5}$ Segundo matéria do Portal Brasil Escola: "As Fake News têm um grande poder viral, isto é, espalham-se rapidamente. As informações falsas apelam para o emocional do leitor/espectador, fazendo com que as pessoas consumam o material "noticioso" sem confirmar se é verdade seu conteúdo. O poder de persuasão das Fake News é maior em populações com menor escolaridade e que dependem das redes sociais para obter informações. No entanto, as notícias falsas também podem alcançar pessoas com mais estudo, já que o conteúdo está comumente ligado ao viés político. [...] Para legitimar as Fake News, as páginas que produzem e divulgam esse tipo de informação costumam misturar as publicações falsas com a reprodução de notícias verdadeiras de fontes confiáveis. Outro problema presente nas redes sociais são as chamadas sensacionalistas que induzem ao erro. Quem deseja espalhar um boato pode retirar de contexto um dado ou declaração para usar em seu título ou no texto de sua postagem. Outra característica das Fake News é a utilização de montagens em vídeos e imagens. O usuário da internet é muito visual, por isso, uma foto manipulada ou fora de contexto pode ser facilmente divulgada como verdadeira". Fonte: <https://brasilescola.uol.com.br/curiosidades/o-que-sao-fake-news.htm>. Acesso em 28 mar. 2019.

${ }^{6}$ Nosso interesse particular pela leitura literária decorre não apenas de nosso próprio percurso profissional e de pesquisa, mas, também, da constatação de que a leitura literária é a menos presente na experiência dos brasileiros, conforme os dados de Retratos da Leitura no Brasil.
} 


\subsection{A literatura e a formação humana em contexto escolar}

Conforme Candido (2011), a literatura é uma manifestação inerente a todo homem, já que parte do imaginário, do fabuloso, do poético, são constantes em nós e constitutivos de nossa condição humana. Contudo, fazer com que essa prática social (a literatura) chegue até os alunos e seja apropriada por eles é, para muitos professores do nível médio de ensino, sinônimo de apresentar uma periodização literária esquemática, que se desdobra no estudo de lista de autores e características atribuídas a cada período, e exemplificada por fragmentos descontextualizados (LEAHY-DIOS, 2000).

Se considerarmos como a finalidade de uma educação literária a formação de sujeitos livres e autônomos que exercitem a sensibilidade e criticidade em direção a uma compreensão mais sofisticada e efetiva do real a partir da mediação ficcional/poética, as escolhas didáticas e pedagógicas do professor revestem-se de uma importância enorme. Muitas vezes, em nossas salas de aula, a leitura do texto literário, as indagações que ele nos propõe, assim como a exploração da linguagem altamente simbólica, ficam em segundo plano, e a literatura passa a não alcançar a sua função social apontada por Candido (2011): a complexificação da compreensão, a sofisticação da sensibilidade e, enfim, a humanização.

Documentos oficiais - como os Parâmetros Curriculares Nacionais do Ensino Médio (PCNEM) e as Orientações Curriculares para o Ensino Médio (OCEM) - têm apontado o texto como o norteador das ações na aula de Língua Portuguesa (dentro das quais se inserem os conhecimentos e experiências literários), mas muitas vezes os professores não têm clareza sobre possibilidades metodológicas diferentes daqueles pelas quais foram eles mesmos formados. Dessa feita, a despeito de todo o avanço teórico obtido em virtude do recrudescente interesse de pesquisadores acadêmicos pelo tema, as práticas de leitura literária em sala de aula são reduzidas a um meio de atingir o fim, qual seja, melhorar a "competência interpretativa" do aluno e, consequentemente, os resultados das avaliações internas e externas à unidade escolar.

Nessa lógica pontuada acima, o texto torna-se um pretexto para as perguntas que serão feitas a seguir. Perde-se todo o potencial formativo (no sentido de emancipatório e reflexivo) da leitura literária, e o jovem distancia-se cada vez mais do hábito de ler, pois o enxerga como tendo por desdobramento necessário uma lista de questionamentos a serem respondidos de maneira objetiva e orientada para uma finalidade definida de antemão.

Diversos estudos já apontam há muito a necessidade de repensar esse tipo de prática pedagógica. Já na década de 1980, Aguiar e Bordini (1988) sugerem em sua obra métodos de mediação de leitura literária que têm como finalidade a leitura crítica, o questionamento das 
leituras realizadas e a transformação dos horizontes de expectativas do leitor. O método semiológico, por exemplo, aponta para práticas pedagógicas que visam ao exercício do pensamento crítico do aluno, e não simplesmente para o consumo do bem cultural, além de buscar indícios de que o aluno, no processo de leitura e diálogo sobre o lido, está discernindo sua função social enquanto intérprete dos textos de sua cultura.

Colomer (2007) também discute sobre a função da escola na formação dos leitores, ou seja, indivíduos que não apenas aprendam, mas que avaliem, através da literatura, como as gerações anteriores e contemporâneas abordam as atividades humanas através da linguagem e suas relações com ela. Para isso, a mediação do professor é imprescindível, pois seu papel vai além de oferecer livros aos discentes. Aspectos como a importância do planejamento didático que crie condições para a leitura de obras literárias são apontados pela autora como necessários nesse processo.

Para alcançarmos os objetivos da Educação Básica no tocante à leitura e à literatura, é urgente, pois, uma abordagem do texto literário em sala de aula que valorize o que este tem a dizer à sociedade e rompa com os métodos que têm "asfixiado" a sua leitura na escola. Isso porque a formação de uma sociedade mais equilibrada e sadia passa pela literatura, afinal, "Que melhor introdução à compreensão das paixões e dos comportamentos humanos do que uma imersão na obra dos grandes escritores que se dedicam a essa tarefa há milênios?” (TODOROV, 2009, p. 93).

A educação para o sensível através da literatura é um dos pilares norteadores deste estudo teórico, com implicações práticas: uma educação mais sensível em si própria, isto é, menos interessada na quantidade de informação a ser transmitida e mais na qualidade de formação humana daqueles nela engajados. Buscamos com nossas reflexões resistir ao embrutecimento das emoções e desenvolver a capacidade de pensamento rigoroso e crítico; por isso, com base na dialética entre nossos estudos e pesquisas e nossa prática docente, apresentamos possibilidades pedagógicas que favoreçam o cultivo do processo humanizador por meio da experiência literária. O que estamos assistindo como fruto do modus operandi atualmente hegemônico é um desenvolvimento tecnológico acompanhado de profundas regressões nos planos social e cultural - e acreditamos que uma educação literária consistente possa contribuir para resistir a isso.

Freire (1967) afirma que o ideal da educação é levar o homem iletrado não à letra, mas à consciência de si, do outro, da natureza. Para o jovem estudante do Ensino Médio, infelizmente, literatura é muito mais uma (sub)matéria escolar a ser aprendida em sua 
periodização do que um agente de conhecimento sobre o mundo, os homens, as paixões, enfim, sobre sua vida íntima e pública (TODOROV, 2009, p. 10). Esta realidade já tem sido apontada também por pesquisadores brasileiros. Chiappini (1983), como uma das precursoras do campo, critica em sua obra o autoritarismo dos professores que veem a literatura como letra morta e se posiciona contrária à ritualização de uma aula que trata os textos literários como saberes instituídos e inquestionáveis.

Em continuidade às discussões iniciadas em Dalvi (2011) e Lourenço (2016), defendemos neste artigo o papel social da literatura quando oportunizada sua apreciação estética, quando a experiência com o texto literário torna-se concreta e a mediação do professor permite ao educando experienciar o mundo por meio da palavra. Defendemos, também, um olhar sobre as possibilidades de exploração do texto literário, a partir de uma experiência de leitura e reflexão a partir de obras dissidentes quanto ao gênero e à periodização, que, contudo, aproximam-se tematicamente.

\subsection{Uma proposta metodológica para a educação literária}

Visando a demonstrar possibilidades na direção sinalizada acima, em diálogo com diferentes pensadores da educação literária, selecionamos dois livros: Boitempo, do poeta Carlos Drummond de Andrade, e Minha vida de menina, de Helena Morley. Ao dispositivo metodológico que aproxima obras de diferentes gêneros, estéticas e períodos, a partir de uma afinidade temática, e que propõe uma dinâmica para o trabalho pedagógico que favoreça a leitura integral das obras pelos jovens leitores inseridos em contexto escolar, estamos chamando de metodologia "temática", pois o foco aproximativo e de exploração está no tema que aproximou as diferentes obras. Aqui, tomamos a noção de "tema" dentro de uma acepção bakhtiniana, ou seja, extrapolando o senso-comum de tema como sinônimo de "assunto" e incluindo uma dimensão axiológico-valorativa.

No caso das obras escolhidas (de Drummond e Morley), procederemos a uma breve análise de como se delineiam as relações familiares a partir do olhar do eu-poético e da narradora nas obras citadas e apresentaremos algumas intervenções didático-metodológicas que podem subsidiar uma prática pedagógica mais dialógica a partir da leitura dos textos literários.

A escolha das obras literárias e a condução de uma leitura significativa, na qual, dentre outras ações, o aluno leitor perceba as incompletudes do texto e aventure-se na atividade inferencial, são possibilidades didáticas, se ainda cremos em uma literatura potencialmente emancipatória em seu sentido ético e político. Para tal, propomos uma escolha metodológica 
alternativa, baseada na aproximação temática, que sirva de opção ao docente que deseja não enveredar tão-somente pela linha histórico-crítica, hoje hegemônica principalmente no ensino médio.

Para potencializarmos as experiências significativas de leitura literária na escola, é preciso repensar a nossa formação de professores e investir na formação de futuros profissionais em relação ao seu verdadeiro papel na sala de aula: o de mediador de um conhecimento que se tem sempre inacabado, sempre em construção dialógica.

A escola de hoje deve ser concebida para uma realidade em que o aluno seja protagonista e o professor tenha papel de relevância, tornando-se o organizador do meio social e dispondose a atuar ativamente e com dinamismo nesse processo. Isso significa dizer que o professor precisa promover situações favoráveis para o aprendizado, impulsionando o discente para o contato com o desconhecido, o novo. Nesse sentido, cabe a esse profissional reconhecer o nível de desenvolvimento real do aluno para, a partir dele, sugerir, por exemplo, a leitura de textos mais complexos e de forma cada vez mais autônoma (VYGOTSKY, 2004).

Esse tipo de abordagem contribui para a valorização do meio cultural e das relações entre os indivíduos na trajetória do desenvolvimento humano. Ao considerar o aluno um sujeito social, que interage com o outro e constrói a aprendizagem em um processo dialógico, o professor assume sua função de mediador, promovendo ações que levem o aluno a pensar o texto a partir de sua visão de mundo, ampliando os horizontes e encaminhando-o à autonomia de pensamento.

\section{Literatura e educação}

\subsection{A leitura literária dialógica}

A literatura é uma manifestação inerente a todo ser humano. Qual seria a função social da literatura? Em primeiro lugar, a literatura é comunicação e, como tal, necessita de um enunciador, um enunciado, a matéria enunciada, e um enunciante, e subjacente a tudo isso um posicionamento no mundo, por meio da discursividade inerente a toda produção de linguagem. Para o escritor, a literatura é a oportunidade de expressão de suas ideias, sentimentos, indignações, admirações etc., sendo, portanto, sua impostação de voz diante dos acontecimentos do mundo. Para o leitor, a literatura representa o seu diálogo com outras ideias, outros sentimentos, indignações, admirações etc. Essa relação dialógica estabelece-se entre leitor e autor através da obra literária, uma matéria organizada que trata, inevitavelmente, de posicionamentos do artista, implícitos ou explícitos, sobre as convenções sociais que o rodeiam. Revista Graphos, vol. 21, n 1, 2019 | UFPB/PPGL | ISSN 1516-1536 
Percebemos, então, que, apesar de sistematizada por um artista e posta em circulação por um processo editorial e comercial, a literatura apresenta a visão de uma coletividade que está à volta desse escritor e que, conscientemente ou não, constrói valores e ideologias que permearão sua obra. Por isso, Candido (2006) afirma que a obra literária surge da confluência entre a iniciativa do autor e as condições sociais em que ele está inserido. Nenhum discurso é neutro e o texto não é indiferente à situação social em que é produzido, conforme conceitua Bakhtin/Volochinov ao afirmar que

[...] o discurso verbal é claramente não autossuficiente. Ele nasce de uma situação pragmática extraverbal e mantém a conexão mais próxima possível com esta situação. Além disso, tal discurso é diretamente vinculado à vida em si e não pode ser divorciado dela sem perder sua significação (BAKHTIN/VOLOCHINOV, 1926, p. 4).

Para o filósofo russo, a palavra está sempre carregada de conteúdo ou de sentido ideológico. Afinal,

[...] não são palavras o que pronunciamos ou escutamos, mas verdades ou mentiras, coisas boas ou más, importantes ou triviais, agradáveis ou desagradáveis etc. [...] É assim que compreendemos as palavras e somente reagimos àquelas que despertam em nós ressonâncias ideológicas ou concernentes à vida (BAKHTIN/VOLOCHINOV, 2004, p. 95).

A palavra, matéria-prima da Literatura, é ponte lançada entre os sujeitos e essa relação com a alteridade ajuda a construir a identidade do leitor. Como procede sempre de um locutor e dirige-se a um interlocutor, a palavra é o território comum a ambos.

O filósofo afirma que "ninguém é herói de sua própria vida" a fim de demonstrar o quanto precisamos do discurso do outro para nos constituirmos. De acordo com os conceitos bakhtinianos, a nossa relação com a realidade é sempre mediada pela linguagem, "o que implica que nosso discurso não se relaciona diretamente com as coisas, mas com outros discursos que semiotizam o mundo" (FIORIN, 2010, p. 167).

O contato com a obra literária é a oportunidade de conhecermos valores construídos em bases ideológicas muito distantes da nossa realidade. É ver pelos olhos do outro aquilo que não posso contemplar com os meus. Esse aspecto é preponderante para a formação da consciência cultural do indivíduo. Como sou autônomo se estou preso a dogmas sociais que nunca avaliei? Como concordar ou discordar daquilo que não conheço? A literatura proporciona esse encontro entre a cultura valorada pelo leitor e aquela que permeia a obra do autor e influenciou em sua elaboração, permitindo o diálogo entre ideologias. 
A partir daí, é possível praticarmos o que Bakhtin (1997) chama de exotopia: colocarme no lugar do outro e, possivelmente, entendê-lo e respeitá-lo, assim como entender-me melhor, já que, segundo o estudioso russo, o outro me vê muito melhor do que eu mesmo me vejo.

Assim, a obra literária extrapola sua função de satisfação da necessidade de fantasia, contribuindo também para a formação da personalidade do indivíduo e do seu conhecimento do mundo.

Quer percebamos claramente ou não, o caráter de coisa organizada da obra literária torna-se um fator que nos deixa mais capazes de ordenar a nossa própria mente e sentimentos; e, em consequência, mais capazes de organizar a visão que temos do mundo (CANDIDO, 2011, p. 177).

Portanto, a função social da literatura se evidencia pela inserção da obra literária nos valores culturais do universo em que é produzida, publicada e apropriada. Mesmo que o autor não tenha a intenção de produzir uma obra classificada como ideológica, seus valores estarão presentes implicitamente nela. Assim, ajuda-nos a organizar e dar forma aos nossos sentimentos, opiniões e visões de mundo, humanizando-nos.

O pensamento bakhtiniano ratifica esse aspecto social da literatura quando conceitua a responsividade:

\footnotetext{
De fato, o ouvinte que recebe e compreende a significação (lingüística) de um discurso adota simultaneamente, para com este discurso, uma atitude responsiva ativa: ele concorda ou discorda (total ou parcialmente), completa, adapta, apronta-se para executar, etc., e esta atitude do ouvinte está em elaboração constante durante todo o processo de audição e de compreensão desde o início do discurso, às vezes já nas primeiras palavras emitidas pelo locutor. A compreensão de uma fala viva, de um enunciado vivo é sempre acompanhada de uma atitude responsiva ativa (conquanto o grau dessa atividade seja muito variável); toda compreensão é prenhe de resposta e, de uma forma ou de outra, forçosamente a produz: o ouvinte torna-se o locutor (BAKHTIN, 1997, p. 290).
}

De fato, a leitura, destacando-se a literária, ultrapassa a reprodução da voz enunciadora do autor. Ela é o ato de percepção de várias vozes que incidem no texto, oriundas dos aspectos históricos e sociais que circundam autor e leitor. Para o alcance dessa função, o leitor deve saborear o texto literário com essa consciência. A mediação da literatura, principalmente na escola, tem sido baseada com insistência na quantidade de leitura "sem o devido adentramento nos textos a serem compreendidos" (FREIRE, 1989, p. 12). Somente esse aprofundamento no texto leva o leitor à reflexão sobre os aspectos postos anteriormente inerentes ao literário. 
É esse leitor responsivo que pretendemos formar através das reflexões e experiência em sala de aula: o leitor que se conscientize do seu papel ativo no ato de ler e que percebe a literatura como ponto de encontro de vários discursos e mediadora entre o sujeito e o mundo.

Nossa prática docente deve estar voltada à formação de um sujeito situado que, "sendo um eu para-si, condição de formação da identidade subjetiva, é também um eu para-o-outro, condição de inserção dessa identidade no plano relacional responsável/responsivo, que lhe dá sentido. Só me torno eu entre outros eus" (SOBRAL, 2010, p. 22).

É através desse conflito entre diferentes valores e interesses sociais que se dá a significação da leitura literária. O leitor reflete, ou refrata, o mundo por meio da leitura.

[...] ao ler, o leitor não apenas espelha ou descreve o mundo que se inscreve nas palavras, mas realiza reflexões, constrói refrações acerca do modo como se revelam nos textos a multiplicidade e as contradições oriundas das experiências históricas das sociedades humanas (ANGELO et MENEGASSI, 2014, p. 666).

Assim, a leitura literária dialógica é uma prática social que leva o homem à discussão e avaliação constantes de seus posicionamentos e ideologias, dando voz ao sujeito leitor como respondente ativo e crítico, encaminhando-o à autonomia do pensamento.

\subsection{Leitura literária: aspectos metodológicos}

A palavra é que organiza o mundo, nomeando e, assim, participando da produção e transformação da realidade. Face a isso, a escola precisa repensar suas metodologias de promoção de leitura literária. O trabalho com o educando deve partir do pressuposto de que a produção de conhecimento pode se dar de forma coletiva, privilegiando o olhar sobre o outro como um sujeito de cultura, opiniões e concepções que podem e devem dialogar com as convicções do docente em busca de melhorias ou soluções para a comunidade.

Sendo assim, a atividade docente deve deixar de ser um ato solitário de transmissão de conhecimentos. O professor que rompe com a neutralidade e se deixa afetar pelas circunstâncias e pelo contexto de sua prática, retorna ao seu lugar de origem também transformado pelas experiências das quais participa.

Ao apregoar o diálogo como premissa maior para a interação entre leitor e obra literária, fundamentamo-nos nos conceitos sobre dialogismo e alteridade de Bakhtin (2010), o qual acredita que a construção da consciência do indivíduo se forma através do olhar e da palavra do outro. Portanto, a experiência leitora nas salas de aula deve buscar considerar a voz do sujeito e suas perspectivas. O diálogo e reflexões acerca dos assuntos em discussão devem, a todo 
tempo, direcionar a organização das intervenções pedagógicas realizadas. A leitura literária pode e deve ser uma experiência significativa para os sujeitos em processo de escolarização.

Porém, a despeito de toda a capacidade que o texto literário possui, acentuando-se a de humanizadora (CANDIDO, 2011), percebemos com a observação das práticas escolares contemporâneas, que o livro de Literatura (sim, em sua concretude) tem se tornado um objeto muitas vezes ausente das aulas de Língua Portuguesa. Percebemos, também, que a corrente utilização do texto literário simplesmente como viés para questões de interpretação de texto é obsoleta e tem colaborado para o tédio que muitos alunos identificam com os momentos de leitura na escola.

É necessário repensarmos esse tipo de prática, tendo em vista que a formação do aluno leitor passa pela produção de sentidos (est)eticamente válidos em relação ao texto e, consequentemente, à vida. A interpretação de informações apresentadas em textos pode e deve ser trabalhada sim, em momento oportuno, e com variedade de gêneros. Porém, esse não deve ser o fim das aulas de Língua Portuguesa. É notório que a excessiva preocupação com o resultado de avaliações internas e externas tem direcionado o tratamento dado ao texto literário na escola como a qualquer outro texto.

Outro aspecto flagrado na observação do cotidiano escolar ${ }^{7}$ é o pouco diálogo que se estabelece sobre a leitura que se fez de um texto. As questões abordadas sobre ele, geralmente, são postas de forma escrita e ao aluno cabe a leitura silenciosa e individual e a produção de respostas mais ou menos previsíveis a esses questionamentos. A oralidade tem sido relegada, nossos alunos têm sido substancialmente silenciados sobre suas percepções acerca do que leram. Acreditamos que a formação de alunos leitores como sujeitos responsivos ativos, conforme conceitua Bakhtin (1997), passa pela potencialização da voz desses sujeitos. A escola é um ambiente privilegiado, onde circulam diversos discursos e valores que precisam interagir a fim de nos formarmos conjuntamente como cidadãos, conscientes de nossa participação ativa no constructo da comunidade em que vivemos. A sociedade não é mais e nem menos que nós. Ela é 'todos nós juntos'.

7 São tomados como base aqui: a) a observação direta em campo e b) os relatórios de estudantes da licenciatura em Letras, matriculados na disciplina de Estágio Supervisionado em Língua Portuguesa e Literaturas em Língua Portuguesa junto à Universidade Federal do Espírito Santo, realizados em turmas de ensino médio, entre 2010 e 2018. 


\section{Uma proposta de metodologia temática}

A fim de oportunizar aos docentes uma alternativa para a mediação da leitura literária que se esquive da já engessada periodização, apresentaremos uma sucinta análise de duas obras que, sempre em resistência à fixação acrítica de indicações etárias, podem se transformar em planejamentos de aulas de Literatura para os anos finais do Ensino Fundamental ou para o Ensino Médio. É fundamental reiterar que, para além da escolha das obras, a metodologia adotada, sempre levando em consideração os aspectos dialógicos já apontados neste artigo, é fundamental para a articulação entre o texto literário e o contexto social-econômico-cultural em que o sujeito leitor está inserido.

A partir de experiências em sala de aula e da análise do acumulado de materiais didáticos produzidos e pesquisas da área, percebemos que a escolha de textos que se aproximam tematicamente, sendo, preferencialmente, de gêneros e/ou períodos literários diferentes, mostra-se como uma estratégia didática interessante, quando se tem como escopo a formação de leitores críticos, autônomos e sensíveis, capazes de perceber os valores ideológicos imbricados nas palavras ditas/escritas (ou não escritas).

Riedel et al. (1971) em seu livro Literatura Brasileira em curso lança, de forma precursora, uma antologia didática que organiza textos literários em torno de temas. A obra busca distanciar-se de uma visão puramente historicista para o ensino de Literatura, procurando desobrigar os textos de uma continuidade baseada em condicionamentos histórico-sociais. Os pesquisadores do campo, desde então, assumem que o ensino de literatura (com enfoque no Ensino Médio) que se atém unicamente à exposição de textos - ou fragmentos - relacionandoos às estéticas literárias às quais estão vinculadas não tem colaborado para o objetivo primordial desse ensino e nem gerado práticas de leitura literária efetivas. Em contrapartida, poucas ${ }^{8}$ são as investigações que se valeram de propostas didáticas, como a citada, a fim de sistematizar atividades docentes que rompam com o método tradicionalmente adotado.

Sabemos que o professor deve levar em conta o programa oficial designativo para cada etapa escolar, porém há uma liberdade metodológica que não foi percebida ainda pela maioria dos profissionais da área. A fim de desentronizar a literatura de um patamar inalcançável (muitos alunos veem a leitura literária como 'coisa para poucos'), a escolha de obras diversas quanto ao gênero, ao período em que foram escritas/publicadas, à voz enunciadora, mas que

8 Utiliza-se como critério a busca por teses e dissertações no site de repositório da Capes (https://catalogodeteses.capes.gov.br/catalogo-teses/\#!/). 
possuem confluências temáticas contribui para a percepção que já apregoamos neste artigo, de que a literatura é plena de saberes sobre o homem e sobre o mundo, tendo o poder de se metamorfosear em diversas formas discursivas (COSSON, 2014).

Pretendemos, pois, com essa alternativa metodológica evitar o trato que majoritariamente tem se dado ao texto literário em sala de aula, alçando-o a uma posição hierarquicamente superior aos discentes, na forma de textos que, sem uma mediação que possibilite a fruição e reflexão sobre a obra, tornam-se escusos e obsoletos. Concordamos que muitos fatores colaboram para que os professores de Literatura continuem a reproduzir o processo didático-metodológico a que estão habituados. Em contrapartida, acreditamos que as pesquisas do campo, que amplamente apontam como inconsistentes e ineficazes tal escolha metodológica arraigada na cultura escolar, precisam reverberar na prática pedagógica dentro das salas de aula, sendo essa a nossa inquietação como docente e o propósito do presente artigo.

Nessa ambiência, selecionamos dois livros em busca de uma aproximação temática: Boitempo, livro memorialístico em versos do consagrado poeta Carlos Drummond de Andrade, e Minha vida de menina, uma obra em forma de diário de Helena Morley (pseudônimo de Alyce Dayrell Caldeira Brant). A escolha das obras justifica-se pela heterogeneidade dos mecanismos literários de enunciação textual (um texto em verso e o outro em prosa) e das vozes enunciadoras (um eu-poético masculino e uma narradora em primeira pessoa), além da distância que separa os dois autores: muito menos cronológica (aproximadamente duas décadas entre as duas publicações) que de notoriedade (Drummond, um dos poetas mais proeminentes de toda a Literatura Brasileira; Helena Morley, avultando seu reconhecimento mais recentemente com a indicação de sua obra na lista de leituras obrigatórias da Fuvest 2018 e 2019).

Além disso, destacamos a notoriedade das obras selecionadas tomando como parâmetro a apreciação crítica que receberam. A primeira edição de Minha vida de menina veio a público em 1942, tendo contado com uma boa recepção crítica por parte de escritores como Alexandre Eulálio, Carlos Drummond de Andrade, João Guimarães Rosa e, mais recentemente, Roberto Schwarz (que dedica à obra boa parte de seu livro Duas meninas). Boitempo também já foi objeto de estudo em dissertações e teses, além de ter obtido a leitura crítica de Antonio Candido e José Guilherme Merquior.

A presença de um posicionamento contestador do status quo em ambas as produções foi o que encetou nossa análise, que poderia/pode se expandir para outras obras de épocas diversas, de autores brasileiros ou não, fora da composição memorialística, em outros suportes, enfim, levando o sujeito leitor a confrontar a diversidade do literário: diversidade dos gêneros, histórica 
e geográfica (ROUXEL, 2013). Dessa maneira, desentroniza-se a periodização literária da forma como tem sido colocada (maçante e mau-humorada) em prol de leituras (reais) que construam pontes entre a literatura e a vida, a partir de temas que nos são comuns e que foram/são explorados pelos escritores em seus mais diversos matizes.

Dentre os vários temas que poderíamos abordar de forma comparativa a partir da apreciação das duas obras, selecionamos as relações familiares como mote para a nossa análise, tendo em vista a constante tensão entre o eu-poético de Boitempo e a narradora de Minha vida de menina frente às convenções sociais tradicionalmente estabelecidas à época de produção das obras. A denúncia de uma sociedade patriarcal evidencia-se ao reunirmos fragmentos de memórias que, juntos, compõem um painel de resistência e inquietação diante de um país que ensaia seus primeiros passos como república (no caso do texto narrativo) e que, alguns anos depois, declina pela repressão de um regime ditatorial (veladamente representado nos versos de Drummond).

Nos contextos citados, entendemos que a família funcionava como um pequeno modelo de como as relações sociais eram reguladas pelas disputas simbólicas travadas no âmbito político do país. Analisaremos, a seguir, alguns fragmentos das obras em apreço que trazem a baila o potencial reflexivo da literatura, apresentando-se como uma forma crítica e criativa de resistência em contextos repressivos (DALVI, 2017).

\subsection{Marcas de uma sociedade patriarcal em Boitempo}

A obra intitulada Boitempo foi publicada por Drummond em 1968 e é o primeiro livro do poeta dedicado integralmente às memórias. A ele segue a publicação de Menino antigo (1973) e Esquecer para lembrar (1979). Essas três obras, de temática memorialística, são condensadas, na década de 1980, em um só livro que permanece com o título da primeira publicação e torna-se um referencial biográfico sobre o autor mineiro. Boitempo conta, fragmentariamente, passagens da infância e adolescência do poeta em suas relações com a família e com as organizações sociais com as quais conviveu. O livro é dividido em sete seções.

Em um contexto patriarcalmente estabelecido, a figura de poder primário reside sobre um homem adulto, geralmente o pai, o qual mantém as funções de liderança e autoridade sob seu domínio. Essas concepções são claramente visíveis em alguns poemas de Boitempo, como veremos a seguir no fragmento de Fim da casa paterna. 


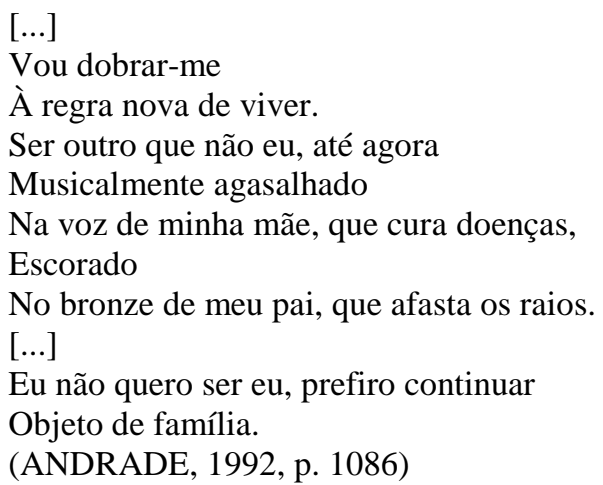

O poema em apreço abre a seção "Primeiro Colégio" e relata a despedida do menino interiorano das pessoas e coisas familiares para iniciar uma nova fase em um colégio interno na capital. É notório, pela leitura dos versos, uma demonstração de medo do novo, do não conhecido. Ao se despedir dos pais, a referência à mãe é feita através de palavras afáveis como 'musicalmente', 'agasalhado' e 'cura', enquanto as escolhas lexicais que aludem ao pai sempre remetem à solidez e à força: 'bronze' e 'raios' no fragmento reproduzido. Em outros fragmentos encontramos reforços para essa opção vocabular. Ainda no poema "Fim da Casa Paterna", o pai é descrito como 'meu pai-imperador'; em "Gesto e Palavra”, o pai é chamado por uma terceira voz de 'coronel'; em “Distinção”, o pai é ‘imenso', reforçando a imagem de autoridade que lhe cabia naquele sistema.

É importante, ainda, destacarmos a despersonalização do eu-poético presente no fragmento extraído. Quando afirma "Eu não quero ser eu, prefiro continuar / objeto de família", percebemos um movimento contrário ao que se dá quando um escritor utiliza a personificação como figura de linguagem. Aqui, ao contrário, há uma objetificação do ser humano - pois o sujeito poemático declara preferir continuar "objeto" de família. Podemos compreender que, em sua posição infantojuvenil, cabia ao menino o papel de dobrar-se, moldar-se ao sistema em que estava inserido e reproduzi-lo. Como instrumento de denúncia presente em vários trechos da obra, Drummond usa a ironia para incitar o leitor à reflexão de que ser um objeto de família (estático receptor do autoritarismo vigente) implica em não ser ele mesmo, em não se constituir como sujeito de sua própria existência.

No poema "Banho de bacia", encontramos o discurso de poder representado pela voz da criança em contraposição a uma voz de adulto que atravessa a enunciação do eu-poético. Observemos como a indiferença ao grito do menino é um apontamento ao papel que cabia à voz da criança no contexto familiar de então, uma figura e reflexo dos discursos de domínio. 


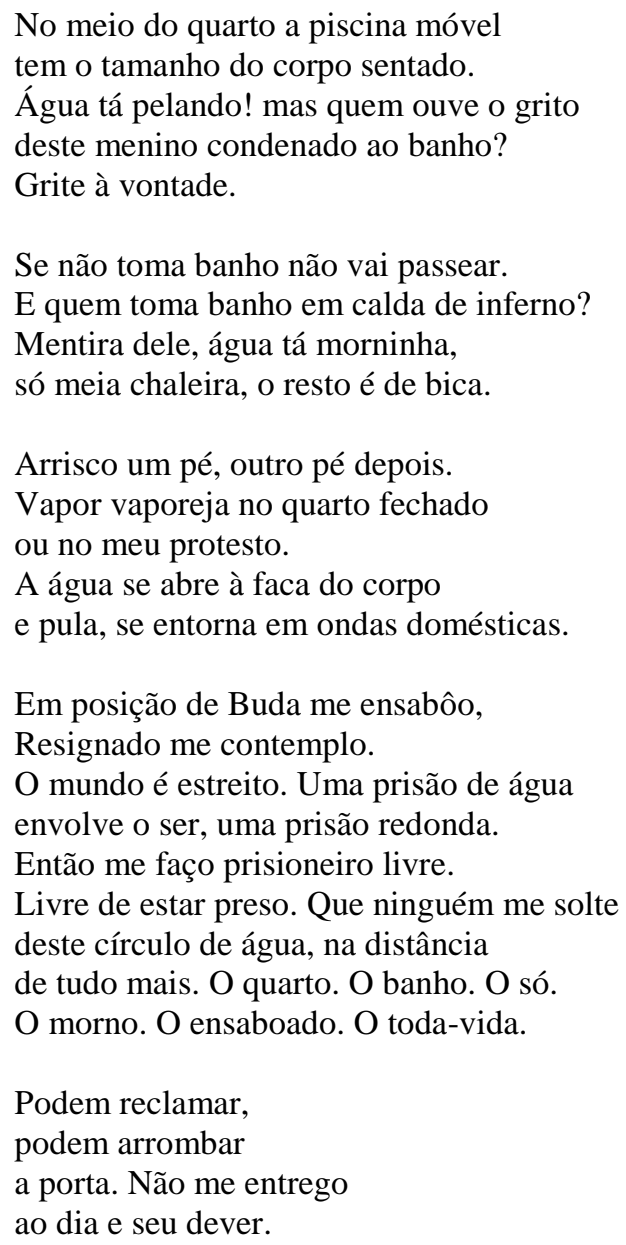

(ANDRADE, 1974, p. 105-6)

Ancorados na noção de polifonia de Bakhtin/Volochinov (2004), para quem em um mesmo texto ocorrem diferentes vozes que se expressam, compreendemos que o aparecimento dessas vozes ideologicamente distintas à do menino, e que prevalecem sobre ele, aponta para relações sociais patriarcalmente estabelecidas. "Se não toma banho não vai passear" é um exemplo de intervenção do discurso repressor e hegemônico, para o qual o menino torna-se um 'prisioneiro livre', numa tentativa de se manter em seu próprio mundo e, consequentemente, à margem do mundo dos adultos e seu autoritarismo. É como se ele compreendesse sua condição e desejasse permanecer agora na bacia, "Podem reclamar / podem arrombar / a porta [...]", como uma tentativa de resistência.

Em muitos outros poemas do livro, encontramos interlocuções em que Drummond coloca em evidência a heterogeneidade dos discursos que circundam o menino que nos fala: em "Gesto e Palavra", ele resiste à ordem do pai e é castigado fisicamente por isso, afinal 'Ele precisa é de couro'; em “Livraria Alves”, já na fase escolar da obra, uma voz tenta reprimir-lhe o desejo de ler livros não autorizados pela escola '(não leiam! Obra excomungada pela Igreja)'; 
no poema "Segundo Dia", ao declarar-se anarquista aos colegas de escola, surpreende-os '[...]como? / O quê? Por quê? Explica essa besteira'.

Percebemos, portanto, que tanto em ambiente familiar quanto escolar, o nosso eupoético vê-se diante de discursos com um conteúdo ideológico distinto ao seu, configurando, por esse motivo, momentos de tensão em que a sua voz parecia não prevalecer diante da imposição do pátrio poder ou do controle do internato ou da força física dos colegas e irmãos mais velhos. Notamos que a escolha pelas memórias em versos para contar sua biografia foi, para Drummond, uma alternativa visando ao questionamento das relações de poder em uma organização social patriarcalmente constituída (o que poderia manter relações com o fato de, no momento de escrita das memórias poéticas, o intelectual Drummond viver um contexto autoritário / repressivo).

\subsection{Minha vida de menina}

Em Minha vida de menina, a adolescente Helena Morley narra o seu dia a dia a partir de anotações que faz em um diário. A história ambienta-se em Diamantina (MG) e pertence ao final do século XIX (1893 a 1895). Segundo Nota à $1^{\text {a }}$ edição, foi o pai da autora quem a orientou a fazer diariamente anotações sobre o mundo à sua volta. Em 1942, o livro é lançado trazendo não somente as cenas do cotidiano de uma família mineira, mas também os comentários agudos da menina sobre a cidade e a família com seus costumes e relações sociais tradicionalmente constituídos.

A narradora pertence a uma família que padece com a decadência da extração de diamantes. Porém, tendo uma origem abastada e com as constantes ajudas financeiras da avó, sua família desfruta de grande prestígio na região. Estamos no ano de 1893, momento em que, apesar da escravidão já estar oficialmente abolida, o trabalho livre ainda não se estabelecera nem a velha sociedade patriarcal se desintegrara, aspectos que percebemos na entrada do dia 27 de abril. Na ocasião, Helena narra um desentendimento de casal entre a negra Magna e um negro africano chamado Mainarte. Importante percebermos como a situação do ex-escravo permanece alheia a condições que ultrapassem a busca pela sobrevivência. A despeito da (imaginada) liberdade que passaram a gozar após a Lei Áurea, Mainarte busca na avó de Helena uma autoridade que resolvesse os problemas conjugais que vivia. A matriarca tenta uma intervenção, sem sucesso. A seguir, a negra é presa por tentativa de assassinato contra o companheiro. A avó de Helena intervém, junto à autoridade judicial, e consegue, sem muito esforço, a soltura de Magna. Esse episódio demonstra a configuração de uma sociedade 
patriarcal em que a hierarquia entre as famílias, e até mesmo entre estas e as autoridades locais, constituía-se baseada no patrimônio.

Em outros fragmentos da obra, encontramos mais evidências de uma sociedade que confere autoridade a quem possui controle de propriedades e de um modelo familiar que reflete esse sistema: as constantes insinuações de inveja dos membros da família à tia Aurélia pela sua situação financeira abastada; o questionamento de Helena se a preferência de sua avó pelo tio Geraldo era por este ser rico; as ajudas financeiras que a avó concedia de forma velada para não constranger os pais da menina; a autorização que D. Teodora tem dos padres para acompanhar de casa os sacramentos.

Apesar disso, encontramos nos registros de Morley uma voz enunciadora que, muitas vezes, questiona explicitamente esse regime. Helena pensa em sua independência financeira em busca de ajudar a família a sair da situação em que se encontra: "Eu, tirando meu título de normalista, sei que tudo vai melhorar" (MORLEY, 2010, p. 71). Porém, questiona a escolarização que recebe, transmitindo uma imagem de escola como um lugar do qual todos querem se livrar: "Ainda não comecei a estudar e já estou pensando nas férias" e "Há certos dias em que eu venho da Escola tão enjoada de tudo, que não tenho ânimo de trabalhar nem de estudar" (MORLEY, 2010, p. 25 e 92). A menina expressa, ainda, um sentimento de inquietude frente a mundo adulto que não a compreende ou considera: “Aqui na Chácara se eu não como, é para incomodar vovó; se eu estudo, é para incomodar vovó; se eu sumo, é para incomodar vovó. Posso lá viver este suplício a vida inteira? [...] É uma coisa esquisita esta vida. Ninguém sabe o que a gente é por dentro, só querem falar o que entendem" (MORLEY, 2010, p. 89).

Por sua intrepidez, Helena está sempre em destaque nos ambientes que frequenta, o que constantemente é motivo de repreensão e tentativa de silenciamento (pelos pais, pelas tias, pela avó, pela escola), o que torna, muitas vezes, a menina confusa sobre a posição que se espera dela nas relações que estabelece. Percebemos, portanto, que as impressões pessoais da narradora transparecem as indagações de uma adolescente que se encontra em uma fase intermediária entre a infância e a vida adulta e que vivencia um momento histórico também de transição. Morley utiliza o papel em branco para expor tanto seu encanto pela vida quanto os desconfortos vivenciados naquele meio social.

\subsection{Utilizando a metodologia temática}

Face à apresentação das duas obras (de Drummond e Morley) que foi feita nas linhas precedentes, a partir do recorte em torno do aspecto familiar, sugerimos que o professor possa 
indicar sua leitura e favorecer condições para que esta efetivamente aconteça (inclusive, por exemplo, reservando tempo da aula para a leitura partilhada de alguns trechos de ambos os livros). Outra alternativa possível é a divisão da turma em dois grandes grupos que fariam simultaneamente a leitura de uma ou outra das obras.

Durante os momentos de leitura, é fundamental que o professor, em seu papel de mediação, instigue os alunos a reflexões acerca do que está sendo lido. Esse momento de leitura coletiva, compartilhada e mentoreada é importante para a construção dialógica acerca dos aspectos simbólicos presentes na linguagem literária.

Após a leitura completa das duas obras, algumas questões-chave podem ser propostas aos estudantes para debate: qual é a estrutura familiar em cada obra? De que forma o gênero memorialístico favorece ou não a tematização de relações familiares? Como a voz enunciativa se relaciona e se posiciona em relação à estrutura familiar e seus vínculos com a sociedade que é sua contemporânea? Que elementos do(s) texto(s) nos permitem chegar a essas conclusões? Qual é o paralelo que se pode fazer com o nosso momento contemporâneo? Como o momento de escrita das obras impacta sua produção? Como o nosso momento de leitura impacta os sentidos que produzimos? Etc.

Após o debate, podem ser desenvolvidas diversas atividades de sistematização e aprofundamento. Os alunos podem produzir um trabalho escrito, coletivo ou individualmente, a fim de sintetizar formalmente as ideias debatidas no grupo. Além disso, é possível promover algumas análises de viés comparativo entre o eu-poético de Boitempo e a narradora de Minha vida de menina, procurando destacar seus perfis enquanto adolescentes historicamente situados em seus contextos de origem.

E, em paralelo, justamente para instrumentalizar a discussão, é provável que surja a necessidade de ensino-aprendizagem de conceitos e de uma metalinguagem do campo literário (que, aí sim, passaria a fazer sentido).

Os alunos podem ser incentivados a fazer registros memorialísticos, seja em prosa ou em verso, a partir das suas observações sobre o cotidiano. É possível, ainda, que seja criado um blog comunitário (espécie de diário virtual) em que os textos produzidos possam ser publicados periodicamente. O professor deve promover as reflexões sobre as diferenças de escolha de registro que incidem sobre o fato de estarmos diante de suportes diferentes (diário/livro e blog).

Pode-se, ainda, sugerir a leitura de outro livro de caráter memorialístico, como Transplante de Menina (Tatiana Belinky), Anarquistas, graças a Deus (Zélia Gattai), Nas ruas do Brás (Dráuzio Varella) ou Poemas da recordação e outros movimentos (Conceição Evaristo) 
em busca de verificar de que forma as relações familiares se estabelecem nos contextos lidos, promovendo uma comparação que considere os momentos de escrita das obras, como a voz enunciadora se posiciona e quais as impressões do aluno ao ler esses textos na contemporaneidade. Acreditamos que essa leitura pode ser estimulada pelo professor a partir de uma lista de sugestões dentre as quais o estudante poderá escolher. Recomendamos que a escolha da obra e a leitura ocorram, nesse segundo momento, de forma individual, a fim de fomentarmos a construção da autonomia do discente enquanto leitor. Os aspectos comparados devem ser alvo de uma aula dialogada em que os alunos que leram as mesmas obras compartilhem suas impressões e, posteriormente, registrem em um texto argumentativo produzido coletivamente nos grupos de comum leitura.

Os registros dos alunos podem ser sistematizados por eles em um infográfico que evidencie os pontos de contato entre os livros, assim como as divergências, e as impressões de leitura, de forma a compor um painel. O trabalho pode ser impresso em um tamanho considerável e exposto em algum ambiente escolar de intensa circulação a fim de estimular o interesse de outros estudantes e/ou servidores da instituição sobre as obras citadas.

\section{Considerações finais}

Acreditamos que a construção de uma sociedade mais equânime passa pela democratização do conhecimento. E, nesse contexto, a educação formal cumpre um papel protagonista a partir do momento que oportuniza a construção de uma consciência crítica coletiva. Em tempos de resistência, é preciso estar atento e ter anelo por uma prática pedagógica que busque a autonomia de pensamento frente aos modelos impostos pelos poderes constituídos. Entendemos que a Literatura é um caminho possível para a concretização de tal intento.

Diante da breve análise que construímos a partir das obras de Drummond e Morley/Brant, podemos tecer alguns apontamentos sobre como as relações familiares experienciadas pelos autores e presentes nas obras podem revelar uma atitude questionadora das vozes enunciadoras dos textos.

Tanto a prosa de Morley quanto os versos de Drummond põem em evidência sujeitos que veem-se deslocados, mesmo em ambientes e convivências 'familiares', o que externa um sentimento de estrangeirismo em sua própria casa. Isso se dá pelo fato de que o detentor do poder e da razão é sempre o outro: o pai, os mais velhos, os professores etc. 
Apesar disso, percebemos que as vozes que nos falam a partir dessas obras buscam sua singularidade e pertencimento social frente a um sistema que propõem o autoritarismo e o pensamento conservador. Essa capacidade de resistência pode ter encontrado na própria literatura, mais especificamente nas memórias literárias, um espaço para a reflexão e a crítica do contexto de inauguração do sistema republicano e oficialização do fim da escravidão ao regime militar repressor, mudanças vivenciadas pelo país durante o interregno de tempo de produção de ambas as obras: final do século XIX até a década de 1970.

Escrever pode ter sido para Morley e Drummond um ato de ressignificação das experiências vividas no passado em busca de uma compreensão que parte do individual para o todo social, buscando nas relações familiares um escopo que analise e revele o espaço que a voz de contestação possuía (ou não) nesses ambientes tipicamente provincianos regidos por um sistema marcadamente patriarcal.

A leitura dessas obras nos leva a questionar, ainda, se essas marcas de autoridade/violência não continuam presentes na forma como se constituem os vínculos familiares e na própria constituição social (política, econômica, educacional e cultural) atualmente. A busca pelo silenciamento em muitos desses contextos revela, por ora, uma resposta positiva a essa questão.

A despeito deste cenário, relembramos que a prática educativa deve apontar sempre para a formação de um sujeito reflexivo que vai interagir socialmente e constituir a coletividade. Esse, sim, o fim desejado da Educação: a constituição de cidadãos autônomos e conscientes de seus papéis sociais.

A lógica da racionalidade atua de forma pragmática estabelecendo a imagem de uma escola que reproduz a sociedade em vez de questioná-la, colaborando, consequentemente, para uma visão de mundo mecânica e limitada. Por isso, buscamos, a partir deste estudo, indicar possíveis alternativas metodológicas em busca de uma leitura literária mais significativa no ambiente escolar. O professor, no contexto mencionado, possui papel ímpar: enquanto mediador, cabe a ele a escolha das obras e a melhor estratégia metodológica para cada ocasião; enquanto pesquisador, está incumbido de buscar a compreensão dos fenômenos, colaborando para a problematização constante de questões atinentes a este campo.

O processo educativo, sobre o qual refletimos neste trabalho, só faz sentido se cremos que o homem é um constante vir-a-ser. "O caráter inacabado dos homens e o caráter evolutivo da realidade exigem que a educação seja uma atividade contínua" (FREIRE, 1980, p. 81). Portanto, a educação deve ser problematizadora em sua constituição. Professores e gestores devem se conscientizar do caráter formativo crítico da área em que atuam, buscando novas 
estratégias, mudanças de metodologia e reflexões acerca de seus papéis frente à formação cidadã com o fito de uma transformação social que pode irromper dentro das salas de aula.

\section{Referências}

AGUIAR, V.T. de; BORDINI, M. da G. Literatura: a formação do leitor - alternativas metodológicas. Porto Alegre: Mercado Aberto, 1988.

ANDRADE, C. D. de. Menino Antigo: Boitempo II. 2ª ed. Rio de Janeiro: Sabiá, 1974.

ANDRADE, C. D. de. Obras completas: poesia e prosa. Rio de Janeiro: Nova Aguilar, 1992.

ANGELO, C. M. P.; MENEGASSI, R. J. Perguntas de leitura na prática docente em sala de apoio. Revista Brasileira de Linguística Aplicada. Belo Horizonte, v.14, n.3, p.661-688, 2014. Disponível em: < http://www.scielo.br/pdf/rbla/v14n3/aop5314.pdf>. Acesso em: 28 dez. 2018.

BAKHTIN, M. M. Estética da criação verbal. São Paulo: Martins Fontes, 1997.

BAKHTIN, M. M. Para uma filosofia do ato responsável. Tradução: Valdemir Miotello e Carlos Alberto Faraco. São Carlos: Pedro \& João Editores, 2010.

BAKHTIN, M. M.; VOLOCHINOV, V. N. Discurso na vida e discurso na arte (sobre poética sociológica). Tradução de Carlos Alberto Faraco e Cristóvão Tezza [para fins didáticos]. Versão da língua inglesa de I. R. Titunik a partir do original russo, 1926.

BAKHTIN, M. M. Marxismo e Filosofia da Linguagem. Tradução: Michel Lahud e Yara Frateschi Vieira. 11 ed. São Paulo: Hucitec, 2004.

CANDIDO, A. O direito à Literatura. In: Vários escritos. 5 ed. Rio de Janeiro: Ouro sobre azul, 2011.

CANDIDO, A. Literatura e sociedade. Rio de Janeiro: Ouro sobre Azul, 2006.

CHIAPPINI, L. Invasão da catedral: literatura e ensino em debate. Porto Alegre: Mercado Aberto, 1983.

COELHO, N. N. Literatura e leitura em tempos de internet. Via Atlântica. São Paulo, n. 14, p. 75-80, dez. 2008. Disponível em:

http://www.revistas.usp.br/viaatlantica/article/view/50381. Acesso em: 28 dez. 2018.

COLOMER, T. Andar entre livros: a leitura literária na escola. São Paulo: Global, 2007.

COSSON, R. Letramento literário: teoria e prática. 2 ed. São Paulo: Contexto, 2014.

DALVI, M. A. Memórias literárias da escolarização (1890-1910): Drummond \& Morley.

Anais da XV ABRALIC, p. 4223-4234, 2017a. Disponível em: <

http://www.abralic.org.br/anais/arquivos/2016_1491436935.pdf >. Acesso em: 15 abr. 2018. 
DALVI, M. A. Invenção da memória escolar pela via do humor em Boitempo. In: VIEIRA, T. L. (Org.). Humor, língua e linguagem: representações culturais. Cuiabá: Verona, 2017b, [s. p.], $13 \mathrm{f}$.

DALVI, M. A. Uma aproximação dialética: memórias poéticas da escolarização. In: PEREIRA, D. de C. (Org.). Nas linhas de Ariadne: literatura e ensino em debate. Campinas: Pontes, 2017c, p. 273-294.

DALVI, M. A. Memórias literárias da escolarização (1890-1910): Drummond \& Morley. In: XV Encontro da Associação Brasileira de Literatura Comparada (Abralic). 19 a 23 de setembro de 2016. Rio de Janeiro. Anais eletrônicos do XV Encontro da Associação Brasileira de Literatura Comparada (Abralic). Rio de Janeiro: Abralic, 2016. v. 1. p. 4223-4234.

DALVI, M. A. Drummond, a crítica e a escola: a invenção de um poeta nacional pelo livro didático de ensino médio. Vitória: Edufes, 2011.

DALVI, M. A.; CAMARGO, G. O. de. Memória poética da escolarização em Boitempo. In: RIBEIRO, R. R.; FIÚZA, S.; FERREIRA, A. M. (Org.). Inscrições da Memória. Goiânia: Ed. UFG, 2017, v. 1, p. 117-137.

DALVI, M. A.; SALGUEIRO, W. Cultura escolar e memória poética: interrogações à educação literária brasileira com Boitempo, de Drummond. In: SIELP V FIAL: Simpósio Internacional de Ensino de Língua Portuguesa, Fórum Ibero-Americano de Literacias, 2016, Minho. Atas do SIELP V FIAL: Simpósio Internacional de Ensino de Língua Portuguesa, Fórum Ibero-Americano de Literacias. Minho: Universidade do Minho. Instituto de Educação. Centro de Investigação em Educação, 2016. p. 193-201.

FAILLA, Z. (Org.). Retratos da leitura no Brasil. 4ª ed. Rio de Janeiro: Sextante, 2016.

FIORIN, J. L. Interdiscursividade e intertextualidade. In.: BRAIT, B. (Org.). Bakhtin: outros conceitos-chave. São Paulo: Contexto, 2010.

FREIRE, P. Educação como prática da liberdade. Rio de Janeiro: Paz e Terra, 1967.

Conscientização: teoria e prática da libertação: uma introdução ao pensamento de Paulo Freire. 3 ed. São Paulo: Moraes, 1980.

A importância do ato de ler: em três artigos que se completam. Autores associados: Cortez, 1989.

LEAHY-DIOS, C. Educação literária como metáfora social: desvios e rumos. Niterói: Ed. UFF, 2000.

LOURENÇO, Suéllen Miotto. A formação do leitor literário no ensino fundamental II por meio da literatura produzida no Espírito Santo. Dissertação (Mestrado Profissional). Instituto Federal do Espírito Santo / Universidade Federal do Rio Grande do Norte, 2016.

MORLEY, Helena. Minha vida de menina. Belo Horizonte: Boa Viagem, 2010.

RIEDEL et al. Literatura Brasileira em Curso. $4^{\mathrm{a}}$ ed. Rio de Janeiro: Bloch Editores, 1971. 
ROUXEL, Annie. Aspectos metodológicos do ensino da literatura. Tradução: Neide Luzia de Rezende. In.: DALVI, M. A., REZENDE, N. L. de, JOVER-FALEIROS, R. (orgs.). Leitura de literatura na escola. São Paulo: Parábola, 2013.

SOBRAL, Adail. Ato/atividade e evento. In.: BRAIT, Beth (Org.). Bakhtin: conceitos-chave. 4 ed. São Paulo: Contexto, 2010.

TODOROV, Tzvetan. A literatura em perigo. Tradução: Caio Meira. Rio de Janeiro: DIFEL, 2009.

VYGOTSKY, L. S. Psicologia pedagógica. $2^{\mathrm{a}}$ ed. São Paulo: Martins Fontes, 2004.

Recebido em: 10/02/2019 Aceito para publicação em: 11/03/2019 